\title{
PROSES BERPIKIR PROBABILISTIK MAHASISWA S1 PENDIDIKAN BIOLOGI JPMIPA FKIP UAD PADA POKOK BAHASAN TEORI PROBABILITAS
}

\author{
Abdul Taram \\ Mahasiswa S3 Program Pasca Sarjana Prodi Pendididikan Matematika UNNES \\ Sekaran, Gunung Pati, Semarang, Jawa Tengah \\ taromahmad@yahoo.com
}

\begin{abstract}
ABSTRAK
Tujuan dari penelitian ini adalah untuk mengetahui persentase pada empat level proses berpikir probabilistic mahasiswa pendidikan biologi Universitas Ahmad Dahlan. Subyek penelitian ini adalah mahasiswa pendidikan biologi kelas C Universitas Ahmad Dahlan, sedangkan instrument pada penelitian ini adalah peneliti sendiri, soal tes, pedoman pelevelan berpikir probabilistic, pedoman wawancara. Hasil dari penelitian diperoleh bahwa level proses berpikir mahasiswa pendidikan biologi untuk materi pada sub pokok bahasan : (a) ruang sampel, untuk level-1 : 18,18\%, level- 2: 18,18\%, level $-3: 40,91 \%$, dan level-4 : 22,73\%; (b) kejadian dan probabilitasnya, untuk level-1: 13,64\%, level-2 : 27,27\%, level-3 : 27,27\%, dan level-4 : 31,82\%; (c) Variabel random dan probabilitasnya, untuk level-1: 13,64\%, level-2: 36,36\%, level-3: 9,1\%, dan level-4 : 40,91\%.
\end{abstract}

Kata kunci : proses berpikir, berfikir probabilitas, level.

\begin{abstract}
The aim of this study was to determine the percentage of the four levels of probabilistic thinking processes of biology education student Ahmad Dahlan University. The subjects of this study are students of biology education class C Ahmad Dahlan University, while the instrument in this study is the researchers themselves, about the test, the guidelines pelevelan probabilistic thinking, the interview guide. Results of the study showed that the level of the thought processes of biology education students to matter at the sub subject: (a) the sample chamber, for level-1: 18.18\%, level- 2: 18.18\%, level -3: $40.91 \%$, and the level-4: 22.73\%; (b) incidence and probability, for level-1: $13.64 \%$, level-2: $27.27 \%$, a level-3: $27.27 \%$, and the level-4: $31.82 \%$; (c) random variables and probability, for level-1: $13.64 \%$, level-2: $36.36 \%$, a level-3: $9.1 \%$, and the level-4: $40.91 \%$.
\end{abstract}

Keywords: thought processes, thinking probability, level.

\section{Pendahuluan}

Program studi pendidikan biologi merupakan salah satu program studi yang ada di lingkungan FKIP Universitas Ahmad Dahlan di Yogyakarta, dalam kurikulumnya memasukan mata kuliah
Matematika Dasar, salah satu pokok bahasan di dalamnya memuat teori probabilitas. Latar belakang mahasiswanya beraneka rangam dan berasal dari beberapa daerah di Indonesia, sudah barang tentu tingkat 
penguasaan terhadap mata kuliah Matematika Dasar beraneka ragam, hasil ujian tengan semester (UTS) yang diperoleh mereka ada yang sangat tinggi dengan skore 89 (delapan sembilan) dan ada yang sangat rendah dengan sekore 02(dua), dengan rata-rata sebesar 48,95 dan simpangan baku 24,13, data ini menunjukkan kemampuan mereka sangat heterogin, kondisi semacam ini tentu perlu mendapat perhatian serius.

Mengetahui akan potensi para mahasiswa yang diasuh dalam suatu perkuliahan akan sangat membantu tenaga pengajar dalam menyampaikan materi perkuliahan, baik dari sisi pendekatan pembelajaran yang digunakan, maupun dari sisi bobot materi perkuliahan yang diberikan, ataupun bimbingan dan perhatian kepada mereka.Kemampuan para mahasiwa banyak dipengaruhi oleh beberapa factor, baik factor ekternal maupun factor internal, beberapa penelitian menunjukkan bahwa factor internal yang sangat dominan. Salah satu factor internal adalah kemampuan berpikir mahasiswa, dan pada tulisan ini yang menjadi fokus pembahasan adalah mengangkat kemampuan prosesberpikir probabilistic mahasiswa, yang merupakan proses berfikir tingkat tinggi, hal ini dapat dilihat pada penggambaran Paul Soeparno mengenai cirri pokok perkembangan kognitisi seseorang dari Jean Piaget, bahwa logika dan probabilitas diposisikan pada tahap operasi formal (Suprijono, Agus,2012: 22-23). Aspek penting yang dikembangkan dalam pembelajaran matematika adalah mengembangkan kemampuan berpikir peserta didik, terlebih di tingkat perguruan tinggi, sehingga seorang tenaga pengajar harus memperhatikan tujuan ini dalam pembelajaran di ruang kelas.

Kemampuan berpikir probabilistic merupakan salah satu dari sekian varian proses berfikir, dan digolongkan dalam proses berpikir tingkat tinggi. Tingkat atau level berpikir probabilistik yang dikemukakan oleh Jones dkk (1997, 1999 ) ada 4 level sebagai berikut : (a) level 1 (Subjective) :Pemikiran siswa secara terus menerus terikat pada alasan subjektif. (b) level 2 - (Transitional) : merupakan masa transisi antara berpikir secara subjektif dan berpikir secara kuantitatif, yang dicirikan oleh pemikiran siswa yang naïve dan seringkali berubahubah dalam mengkuantitatifkan peluang. (c) level 3 - (Informal Quantitative): Pemikiran pada level iniditunjukkan melalui penggunaan strategi generatif dalam mendaftar hasil eksperimen 2 tahap, dan mempunyai kemampuan menyelaraskan dan mengkuantitatifikasi pemikiran mereka tentang ruang sampel 
dan peluang. (d) level 4 - (Numerical) : Siswa mampu membuat hubungan yang tepat tentang ruang sampel dan peluangnya, dan mampu menggunakan ukuran secara numerik dengan tepat untuk mendeskripsikan peluang suatu kejadian. (Imam Sujadi, 2008)

Menurut Hirsch dan O'Donnell (2001) kesalahan dalam menalar probabilistik dapat terjadi karena miskonsepsi tentang peluang. Penelitian tentang berpikir probabilistik siswa telah diungkapkan oleh beberapa ahli. Salah satu ahli yaitu Amir dan Williams (1995) mengungkapkan bahwa kultur yang meliputi bahasa, keyakinan (keagamaan), dan pengalaman (contoh: permainan) berpengaruh terhadap pengetahuan probabilistik informal siswa. Pengetahuan probabilistik informal (seperti: konsep-konsep informal, intuisi, heuristic, pendekatan hasil, dll) berpengaruh terhadap pemikiran probabilistik siswa. Tingkat pemikiran probabilistik siswa akan mempengaruhi siswa dalam belajar pengetahuan probabilistik formal (seperti: konsepkonsep formal, skill, kombinatorik, dll).

Pada Peraturan Presiden nomor 8 tahun 2012 tentang Kerangka Kualifikasi Nasional Indonesia (KKNI) disebutkan bahwa strata 1 (S1) berada pada level 6, dan pada rumusan alinea ke dua disebutkan :Menguasai teoritis bidang pengetahuan tertentu secara umum dan konsep khusus bagian teoritis dalam bidang pengetahuan tersebut secara mendalam serta mampu memformulasikan penyelesaikan permasalah secara prosedural.(PP No.8 Tahun 2012).

Rumusan tersebut merupakan panduan sehingga setiap komponen yang terlibat dalam penyelenggaraan proses pembelajaran di S1, terutama tenaga edukatip berusaha untuk mengarahkan para mahasiswa agar berada pada level yang sudah ditetapkan.

Atas dasar uraian tersebut, penulis tertarik untuk melakukan penelitian yang terkait dengan proses berpikir probabilistik mahasiswa. Kegiatan ini sebagai usaha penulis untuk mengetahui posisi para mahasiswa, selanjutnya berusaha untuk meningkatkan kemampuan berpikir mereka, dengan demikian diharapkan para mahasiswa memiliki daya saing yang handal, terlebih dalam menghadapi Masyarakat Ekonomi Asean (MEA) yang akan dilaksanakan akhir tahun 2015 atau sekarang ini.

\section{Metode Penelitian}

Pada penelitian ini peneliti melakukan analisis pelevelan terhadap data hasil tes para mahasiswa yang terkait dengan materi probabilitas yaitu : ruang sampel, kejadian dan probabitas suatu 
kejadian, variable random beserta probabilitasnya. Disamping itu peneliti melakukan wawancara terhadap mahasiswa yang dipilih sebagai perwakilan dari masing-masing level pada proses berpikir probabilistic. Sehingga penelitian ini termasuk penelitian diskriptif ekplorasi kualitatif. Data utama dalam penelitian ini adalah hasil tes dengan melakukan pengkategorian untuk pelevelan, dan hasil wawancara.

Sedangkan subjek Penelitian ini adalah mahasiswa pendidikan biologi kelas C Universitas Ahmad Dahlan, AdapunInstrumen dalam penelitian ini adalah peneliti sendiri, soal tes, pedoman pelevelan berpikir probabilistic, pedoman wawancara

Tabel 1.Kerangka Level Berpikir Probabilistik Mahasiswa Pendidikan Biologi JPMIPA FKIP UAD pada Pokok Bahasan Teori Probabilitas

\begin{tabular}{|c|c|c|c|c|}
\hline $\begin{array}{l}\text { Sub Pokok } \\
\text { Bahasan }\end{array}$ & $\begin{array}{c}\text { Level 1 } \\
\text { (Subyektif) }\end{array}$ & $\begin{array}{c}\text { Level 2 } \\
\text { (Transitional) }\end{array}$ & $\begin{array}{c}\text { LEVEL 3 } \\
\text { (Informal - } \\
\text { Quantitative) } \\
\end{array}$ & $\begin{array}{c}\text { LEVEL } 4 \\
\text { (Numerical) }\end{array}$ \\
\hline Ruang Sampel & $\begin{array}{l}\text { - Mengkontruksikan } \\
\text { anggota ruang } \\
\text { sampel tanpa pola } \\
\text { tertentu. }\end{array}$ & $\begin{array}{l}\text { - Membuat sketsa } \\
\text { gambar } \\
\text { pembentukan ruang } \\
\text { sampel. } \\
\text { - Menuliskan } \\
\text { Menuliskan notasi } \\
\text { untuk ruang sampel }\end{array}$ & $\begin{array}{l}\text { - Mengkontruksikan } \\
\text { anggota ruang } \\
\text { sampel dengan pola } \\
\text { tertentu. } \\
\text { - Menuliskan semua } \\
\text { titik sampel dalam } \\
\text { suatu himpunan. } \\
\text { - Menuliskan notasi } \\
\text { jumlah anggota } \\
\text { ruang sampel }\end{array}$ & $\begin{array}{l}\text { - Melakukan } \\
\text { perhitungan } \\
\text { jumlah anggota } \\
\text { ruang sampel } \\
\text { dengan rumus } \\
\text { kombinasi. }\end{array}$ \\
\hline $\begin{array}{l}\text { Kejadian dan } \\
\text { Probabilitasnya }\end{array}$ & $\begin{array}{l}\text { - Mengkontruksikan } \\
\text { anggota suatu } \\
\text { kejadian dengan } \\
\text { tidak mengikuti } \\
\text { pola tertentu }\end{array}$ & $\begin{array}{l}\text { - Mendefinisikan } \\
\text { suatu kejadian dari } \\
\text { ruang sampel }\end{array}$ & $\begin{array}{l}\text { - Mengkontruksikan } \\
\text { anggota suatu } \\
\text { kejadian dengan } \\
\text { mengikuti pola } \\
\text { tertentu. } \\
\text { - Menuliskan semua } \\
\text { anggota kejadian } \\
\text { sesuai dengan } \\
\text { definisi yang } \\
\text { dibuat. }\end{array}$ & $\begin{array}{l}\text { - Menuliskan rumus } \\
\text { untuk menghitung } \\
\text { nilai probabilitas } \\
\text { suatu kejadian. } \\
\text { - Menentukan nilai } \\
\text { probabilitas suatu } \\
\text { kejadian }\end{array}$ \\
\hline $\begin{array}{l}\text { Variabel } \\
\text { Random dan } \\
\text { Probabilitasnya }\end{array}$ & $\begin{array}{l}\text {-Menuliskan notasi } \\
\text { semua titik sampel } \\
\text { - Menentukan semua } \\
\text { nilai yang mungkin } \\
\text { untuk X(a). tidak } \\
\text { lengkap }\end{array}$ & $\begin{array}{l}\text { - Menuliskan notasi } \\
\text { dari variable } \\
\text { random X(a). } \\
\text { - Menentukan semua } \\
\text { nilai yang mungkin } \\
\text { untuk X(a). dengan } \\
\text { lengkap dan benar }\end{array}$ & $\begin{array}{l}\text { - Membuat diagram } \\
\text { panah untuk semua } \\
\text { nilai dari X(a). } \\
\text { - Menggambar } \\
\text { grafik distribusi } \\
\text { probabilitas. }\end{array}$ & $\begin{array}{l}\text { - Menentukan nilai } \\
\text { probabilitas untuk } \\
\text { semua harga } \\
\text { variable random. } \\
\text { - Mengkontruksikan } \\
\text { tabel distribusi } \\
\text { probabilitas varibel } \\
\text { random. } \\
\text { - Memverikasi } \\
\text { jumlah nilai } \\
\text { probabilitasnya } \\
\text { sama dengan } 1 .\end{array}$ \\
\hline
\end{tabular}


Pengumpulan data pada penelitian ini dengan menggunakan metode tes terhadap subyek penelitian, dan metode wawancara terhadap empat mahasiswa untuk mewakili level 1, dua orang mahasiswa untuk mewakili level 2, seorang mahasiswa untuk mewakili level 3, dan empat mahasiswa sebagai wakil dari level 4.
Analisis data dilakukan penelitu dengan berpedoman pada kriteria pelevelan proses berpikir probabilistic yang dikembangkan olen Jones dkk, dengan mengidentifikasikan seberapa besar persentase untuk tiap-tiap materi pada sub pokok bahasan pada masingmasing 4 level tersebut.Hasil analisis terhadap data yang ada sebagaimana tercantum pada tabel 2

Tabel 2.Persentase Level Berpikir Probabilistik Mahasiswa Pendidikan Biologi JPMIPA FKIP UAD pada Pokok Bahasan Teori Probabilitas

\begin{tabular}{lcccc}
\hline \multicolumn{1}{c}{$\begin{array}{c}\text { Sub Pokok } \\
\text { Bahasan }\end{array}$} & $\begin{array}{c}\text { Level 1 } \\
\text { (Subyektif) }\end{array}$ & $\begin{array}{c}\text { Level 2 } \\
\text { (Transitional) }\end{array}$ & $\begin{array}{c}\text { LEVEL 3 } \\
\text { (Informal -Quantitative) }\end{array}$ & $\begin{array}{c}\text { LEVEL 4 } \\
\text { (Numerical) }\end{array}$ \\
\hline Ruang Sampel & $18,18 \%$ & $18,18 \%$ & $40,91 \%$ & $22,73 \%$ \\
$\begin{array}{l}\text { Kejadian dan } \\
\text { Probabilitasnya }\end{array}$ & $13,64 \%$ & $27,27 \%$ & $27,27 \%$ & $31,82 \%$ \\
$\begin{array}{l}\text { Variabel Random } \\
\text { dan Probabilitasnya }\end{array}$ & $13,64 \%$ & $36,36 \%$ & $9,1 \%$ & $40,91 \%$ \\
\hline
\end{tabular}

Dari hasil penelitian ini terlihat bahwa untuk materi "Ruang sampel” persentase yang paling besar padah level3 sebesar 40,91\%, untuk materi "Kejadian dan probabilitasnya" persentase yang paling besar pada level-4 sebesar 31,81\%, dan materi "Variabel random dan probabilitasnya" persentase yang paling besar pada level-4.

\section{Pembahasan.}

Dari hasil wawancara dengan para mahasiswa yang mewakili masingmasing level diperoleh informasi sebagai berikut :

Level 1.
Pada level 1 dipilih 4 mahasiswa yang mewakili. Pada umumnya mereka belum memahami dan belum menguasai materi, walaupun menurut pengakuan mereka mengerjakan soal nomor 1, nomor 2, dan nomor 3 dengan baik, akan tetapi mereka dalam menyelesaikan soal tidak menggunakan strategi.

Mereka merasa kebingungan dengan soal, karena contoh soal yang dibahas dalam perkuliahan tidak sama, dalam perkuliahan warna bola hanya dua, sedangkan dalam soal ada 3 warna.Mereka meneyelesaikan dengan coba-coba tidak menggunakan pola tertentu. Usaha mereka dalam belajar 
belum maksimal, bahkan ada yang 1(satu) mahasiswa dari SMKN kurang berminat dalam mempelajari Kalimantan Timur, 1(satu) mahasiswa matematika.

dari SMAN Timika, dan 1(satu)

Sedangkan dilihat dari asal mahasiswa dari SMAN Banjarnegara sekolah mereka pada level ini 1(satu) Jawa Tengah. mahasiswa dari SMKN Sumatera selatan,

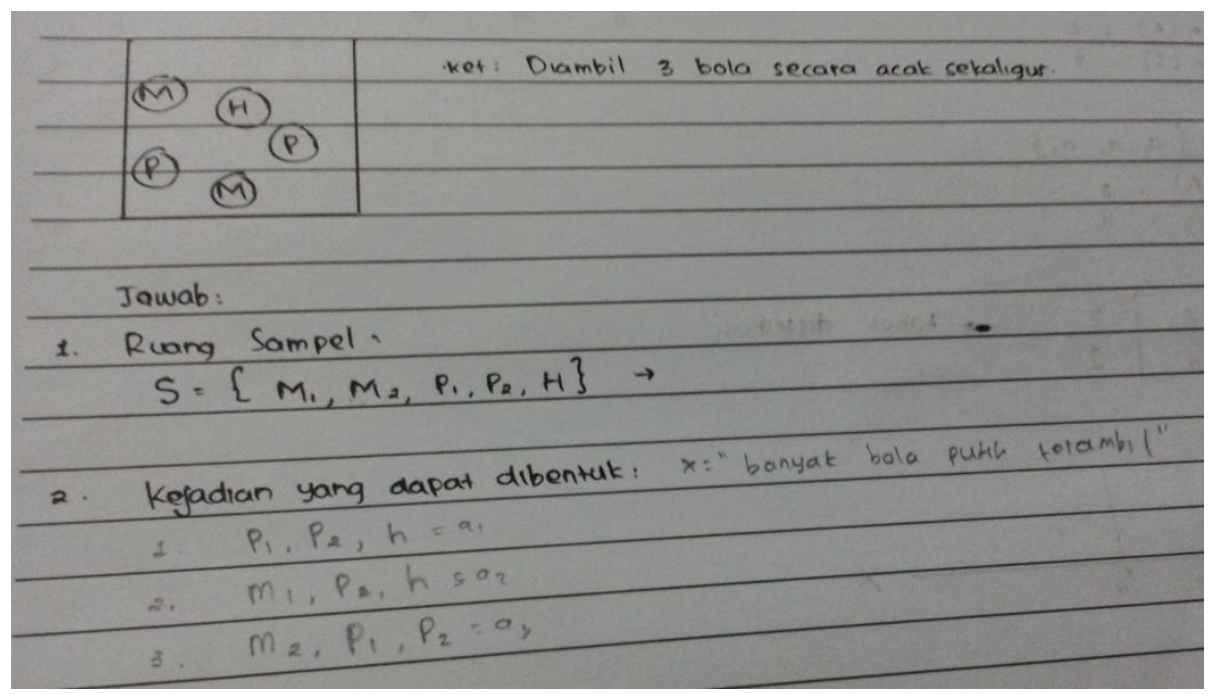

Gambar 1. Contoh lembar jawaban level-1

Level 2

Pada level 2 dipilih 2 mahasiswa yang mewakili. Menurur pengakuan mereka berdua bahwa soal no 1 sampai 5 diselesaikan dengan baik, akan tetapi masih ragu-ragu. Pada umumnya mereka mengerjakan soal dengan coba-coba tidak menggunakan pola tertentu dan tidak menggunakan strategi tertentu. Mereka merasa kesulitan dalam menghitung, bahkan mereka ada yang terpengaruh oleh teman yang lain, mereka secara jujur menyampaikannya. Mereka merasa senang sebenarnya dalam mengikuti perkuliahan. Mereka berasal dari SMAN Prambanan Jateng, dan dari MA Probolinggo Jawa Timur. 


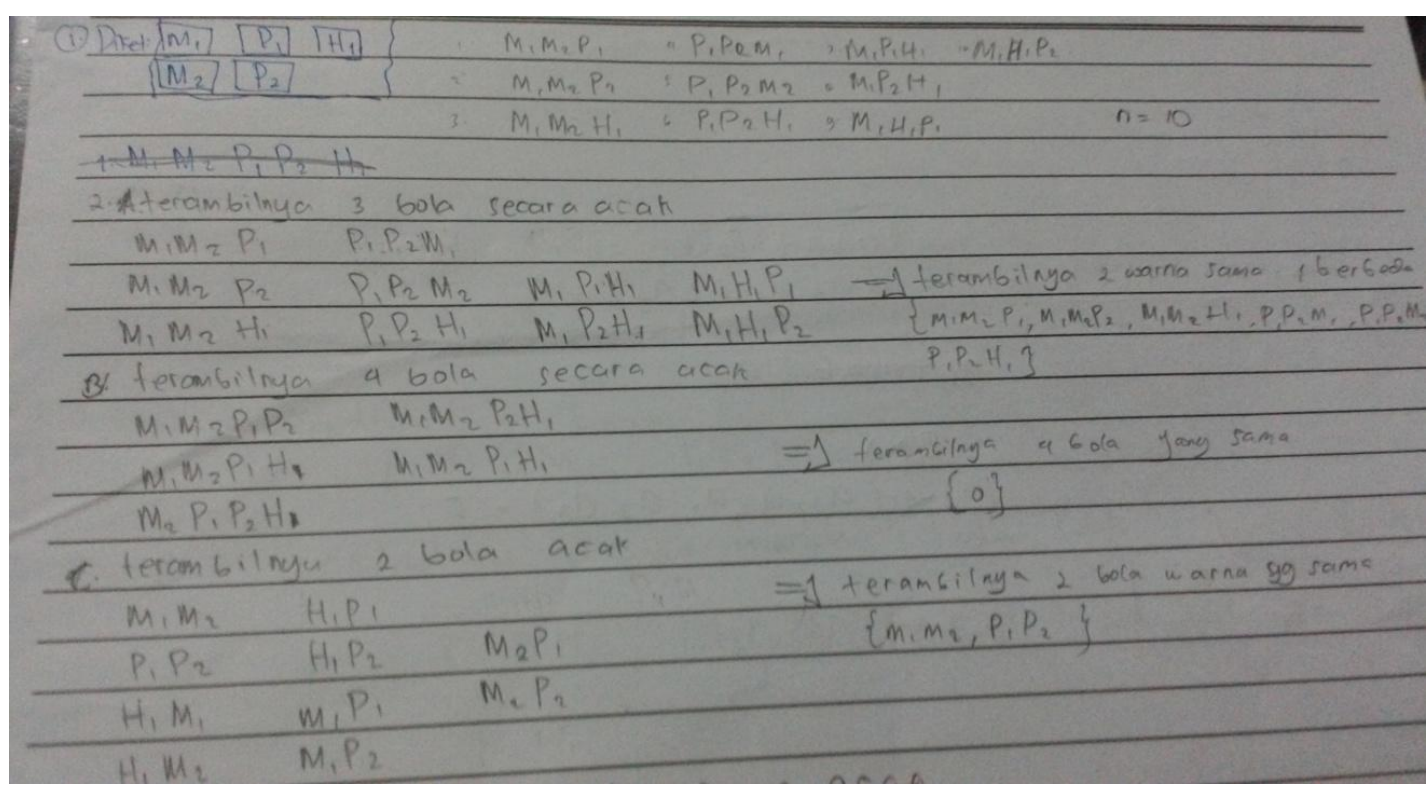

Gambar 2.Contoh lembar jawaban level-2

Level 3.

Pada level 3 ini dipilih 1 mahasiswa yang mewakili. Menurut pengakuannya soal nomor 1 dan 2 diselesaikan dengan sempurna, sedangkan soal yang lainnya masih ragu- ragu. Tidak menggunakan strategi tertentu, masih mengalami kebingungan dalam menentukan nilai variable random, sehingga kurang lengkap dalam melakukan perhitungan. Mahasiswa ini berasal SMAN Kepulauan Riau.

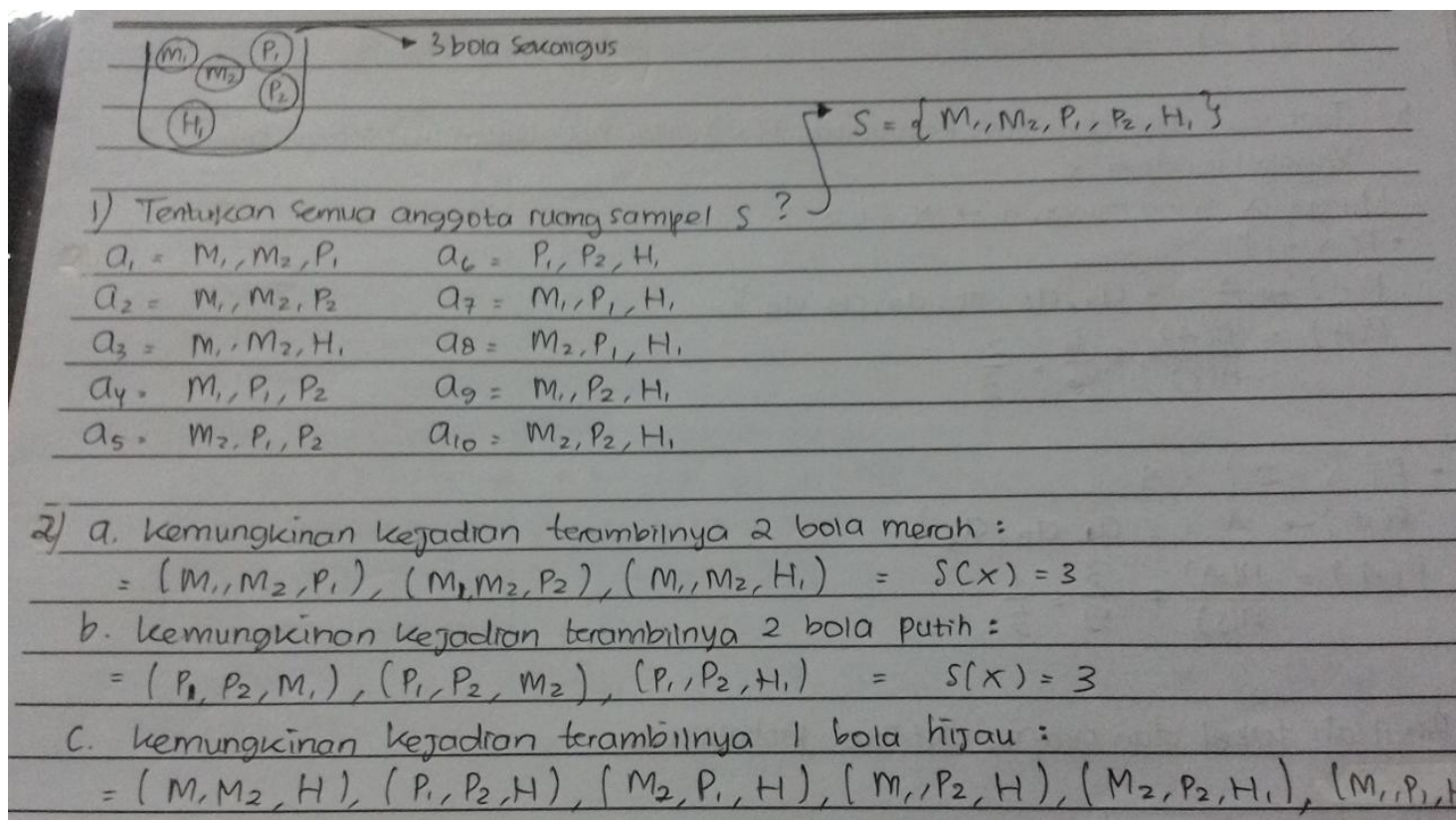

Gambar 3. Contoh lembar jawaban level-3

Level 4.

Pada level 4 ini dipilih 4 mahasiswa untuk mewakili. Pada umumnya mereka menyampaikan telah menyelesaikan soal nomor 1 sampai nomor 5 dengan sempurna. Mereka 
menggunakan strategi dalam Mereka berasal dari SMAN Kelaten Jawa menyelesaikan soal, menggunakan pola tengah sebanyak 3 orang mahasiswa, dan tertentu, dan mereka melakukan 1 orang mahasiswa berasal dari SMAN perhitungan probabilitas dari kejadian Yogyakarta.

dan variable random dengan benar.

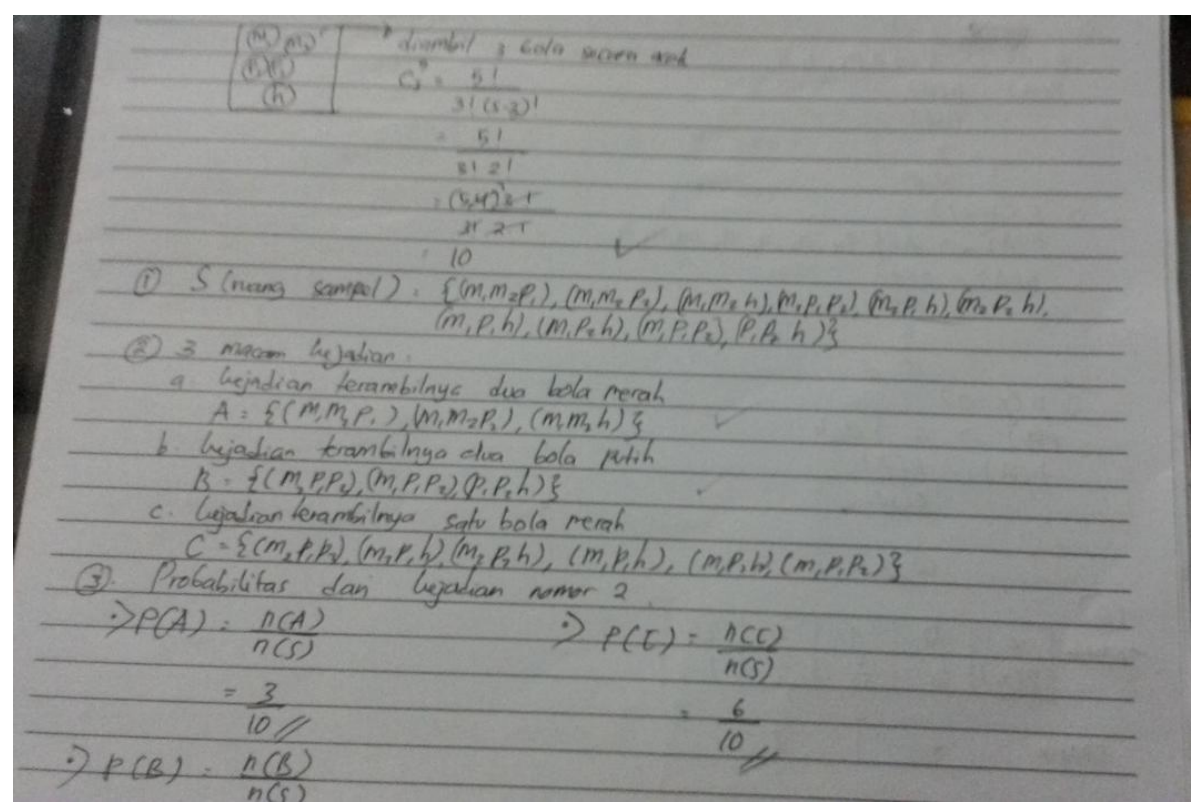

Gambar 4.Contoh lembar jawaban level-4

\section{Kesimpulan dan Saran}

\section{Kesimpulan}

1. Dari hasil penelitian ini terlihat bahwa untuk materi “ Ruang sampel” persentase yang paling besar padah level-3 sebesar $40,91 \%$, untuk materi "Kejadian dan probabilitasnya" persentase yang paling besar pada level-4 sebesar $31,81 \%$, dan materi "Variabel random dan probabilitasnya" persentase yang paling besar pada level-4.

2. Dari hasil wawancara diperoleh informasi bahwa mereka dalam menyelsaikan soal probabilitas yang berada pada level 1 pada umumnya tidak menggunakan strategi dan pola tertentu. Mereka yang berada pada level 2 Pada umumnya mereka mengerjakan soal dengan coba-coba tidak menggunakan pola tertentu dan tidak menggunakan strategi tertentu. Mereka merasa kesulitan dalam menghitung. Mereka yang berada pada level 3 tidak menggunakan strategi tertentu, masih mengalami kebingungan dalam menentukan nilai variable random. Sedangkan mereka yang berada pada level 4 menggunakan strategi dalam 
menyelesaikan soal, menggunakan pola tertentu, dan mereka melakukan perhitungan probabilitas dari kejadian dan variable random dengan benar.

\section{Saran}

1. Mereka yang berada pada level proses berpikir level 1 mayoritas berasal dari luar Jawa, sehingga perlu ada perlakuan khusus dalam pembelajaran, seperti pembimbingan, pemberian tugas; sehingga level proses berpikir probabilistic mereka akan meningkat.

2. Perlu ada penelitian lanjutan berkenaan dengan proses berpikir probabilistic pada mahasiswa program studi yang lain sehingga diperoleh informasi yang lebih konprehensip.

\section{Pustaka}

Jones,G.A, dkk, 1997, A Framework For Assesing and Nuturing Young Children's Thinking in Probability. Educational Studies in Mathematics,32.101-125.

Jones,G.A, dkk, 1999, Student's Probabilistic Thinking in instruction. Journal for research in Mathematics. Educational , 30 487-519.
Jones,G.A, dkk, 1997, A Understanding Student Probability reasoning. Reston, Virginia : The NTCM.

Jones,G.A， dkk， 2002， Elementary Student' Access to Powerfull Mathematical Ideas. Handbook of Internasional Research in Mathematics Education, London: The NTCM,6. 113-141.

Sujadi, Imam, 2008, Rekontruksi TingkatTingkat Berpikir Probabilistik Siswa Sekolah Menengan Pertama,Makalah Seminar Matematika dan Pendidikan Matematika, FKIP UNS.

Syukron Maftuh, M, 2014, Profil Penalaran Probabilistik Siswa SMP Laki-laki dalam pemecahan Masalah

Probabilitas, Makalah Seminar Nasional Pendidikan

Matematika, Surabaya.

Suparno,Paul, 2001, Teori Perkembangan Kognitif Jean Piaget, Yogyakarta : Penerbit Kanisius.

Suprijono, Agus, 2012, Cooperative Learning Teori dan Aplikasi Paikem, Yogyakarta : Pustaka Pelajar. 
